This is the authors' post-print PDF version

of the paper 'Wild dogs and village dogs in New Guinea: Were they different?' which was published in Australian Mammalogy.

Citation details for the published version are:

Dwyer, P. D. and M. Minnegal (2016) Wild dogs and village dogs in New Guinea: Were they different? Australian Mammalogy 38(1): 1-11. DOI: 10.1071/AM15011

\title{
WILD DOGS AND VILLAGE DOGS IN NEW GUINEA: WERE THEY DIFFERENT?
}

\author{
PETER D. DWYER and MONICA MINNEGAL
}

Recent accounts of wild-living dogs in New Guinea argue that these animals qualify as an "evolutionarily significant unit" that is distinct from village dogs, have been and remain genetically isolated from village dogs and merit taxonomic recognition at, at least, subspecific level. These accounts have paid little attention to reports concerning village dogs. This paper reviews some of those reports, summarizes observations from the interior lowlands of Western Province and concludes that: (1) at the time of European colonization, wildliving dogs and most, if not all, village dogs of New Guinea comprised a single though heterogeneous gene pool; (2) eventual resolution of the phylogenetic relationships of New Guinea wild-living dogs will apply equally to all or most of the earliest New Guinea village-based dogs; and (3) there remain places where the local village-based population of domestic dogs continues to be dominated by individuals whose genetic inheritance can be traced to precolonization canid forebears. At this time, there is no firm basis from which to assign a unique Linnaean name to dogs that live as wild animals at high altitudes of New Guinea.

Key words: New Guinea, dogs, chorus howling, tail brush, tail flagging.

P D Dwyer, School of Geography, The University of Melbourne, Victoria, Australia. Email: pddwyer@unimelb.edu.au. M Minnegal, School of Social and Political Sciences, The University of Melbourne, Victoria, Australia. Email:mmam@unimelb.edu.au.

Running Head: Wild dogs and village dogs in New Guinea 
Wild-living dogs have been reported from widely dispersed high altitude localities in New Guinea (Koler-Matznick et al. 2003, 2007). They are popularly known as New Guinea singing dogs in recognition of the facts that they frequently howl and multiple individuals may chorus. Koler-Matznick et al. (2007: 53) argued that the New Guinea wild-living dog qualifies as an "evolutionarily significant unit" and favoured the view that "the singing dog, and pure $C$. dingo, are incipient sibling taxa, and their order of derivation will likely be resolved by further research". They considered, moreover, that, in New Guinea, wildliving dogs are distinct from village dogs, but wrote that "a large number of the Lowland specimens have features that superficially resemble, to some extent, singing dogs" (2007: 53).

Discussion of New Guinea singing dogs has paid insufficient attention to reports concerning village dogs. To this time there have been no ecological or behavioural studies of New Guinea village dogs. Most of the available information is anecdotal (see, however, Schultze-Westrum 2010a,b.c). Nor have there been detailed field studies of wild-living animals though Bino (1996) provides information based on monitoring signs of dogs in the altitude range 1200 to $2800 \mathrm{~m}$, at Mt. Stolle (Sandaun Province). In this paper we summarize published information concerning the morphology, distribution and behaviour of village dogs, together with our own observations gathered in the course of extended visits over a period of 28 years, asking whether, in the past and at present, high-altitude wild-living dogs were or are different from village-based dogs at any altitude.

Because available information is not comprehensive we focus on particular topics. After briefly discussing matters concerning the scientific history, nomenclature and possible relationships of New Guinea dogs, we present comparative information about village and wild-living dogs under the headings 'body form and tail brush', 'colour and pattern', 'distribution and reproductive isolation', 'local knowledge' and 'behaviour (vocalizations, tail flagging and climbing ability)'. Most information purporting to be about wild-living dogs is based on studies of dogs that were bred from animals, of uncertain provenance, obtained in the 1950s and 1970s.

\section{METHODS}

In what follows we draw on anecdotal reports by explorers, Government officers, naturalists, biologists and anthropologists, more detailed accounts by Schultze-Westrum and by Majnep, and our own observations between 1986 and 2014 in an inland region of Western Province. Between 1959 and 2003, in the course of more than 20 visits to New Guinea, Schultze-Westrum made extensive observations on village dogs in the lowlands of both the eastern and western halves of that island and, in the east, in 1966, in the midaltitude Mount Bosavi area of the Western Province (2010a,b,c). Ian Saem Majnep was a Kalam man, living in the upper Kaironk Valley, in the foothills of the Schrader Range in Madang Province, who, working with anthropologist Ralph Bulmer, contributed much to knowledge of the ethnobiology of Papua New Guinea (Majnep and Bulmer 1977, 2006). His account of dogs from the Karionk Valley is the most detailed available based directly on local knowledge (2006: 268-311). He had a good eye for morphological variation and provides details of hunting, ownership and mythology. However, his observations refer to times that follow colonization when at least some of the dogs he discusses were likely to have been partial descendants of introduced types (Bulmer and Menzies 1972: 486).

In 1986-87 we spent 15 months at the village of Gwaimasi on the west bank of the Strickland River, in the interior lowlands of Western Province, Papua New Guinea (latitude $5^{\circ}$ 54' S, approximately 100 m ASL; Dwyer and Minnegal 1992a). We revisited 
Gwaimasi in 1991, 1994, 1995-96 and 1998-99 and, since 2011, have conducted research among people of the same language group (Kubo) based at the Suabi mission station, 35 $\mathrm{km}$ southeast of Gwaimasi (Dwyer and Minnegal 2014). In 1986-87 the number of residents at Gwaimasi averaged 25 across months and the number of domestic dogs in the village varied but was usually of the order of 20 . All were individually named and owned by local people. There were no wild-living dogs in the area. Dogs were important to some strategies of hunting (Dwyer and Minnegal 1991) but, in September 1987, 15 of the 19 then resident dogs died when a distemper epidemic swept through the region. In the period before people re-established a population of village dogs they took the opportunity to establish free-ranging chickens as domestic animals (Dwyer and Minnegal 1992b). At Gwaimasi we recorded the size of the village population of dogs, information on their role in hunting and some details of body form, colour and behaviour. In the years 2011 to 2014 we spent a total of seven and a half months at Suabi mission station. The Kubo population had doubled since 1986-87 and increasing numbers of people had settled at Suabi where, by April 2014, the resident population was 764 and the ratio of domestic dogs to people was approximately 1:10.

The terms 'domestic', 'feral' and 'wild' are all subject to multiple, and often confusing, meanings. We use 'domestic' to refer to cases where the animals in question are under the care of people, including cases where little of the food eaten by the animals is provided by people and all males kept by people are de-sexed (see Dwyer, 1996, re pigkeeping in Papua New Guinea). We use 'feral' to refer to cases where the animals in question live commensally or apart from humans but are known to be derived from 'domestic' animals. And we write of 'wild-living' animals in cases where, again, the animals in question live apart from humans but it is not known whether, or not agreed that, they derive from domestic animals.

\section{HISTORICAL BACKGROUND}

The earliest specimens of dogs to reach beyond New Guinea as museum specimens or live animals included two skulls and skins obtained from the Mount Scratchley area (now in Oro Province, Papua New Guinea) in 1897, a live male and female reported to be from the Lavani Valley (now in Hela Province, Papua New Guinea) in 1956 and five live animals from the Eipomek River valley (now in West Papua, Indonesia) in 1976. The Mount Scratchley specimens have been reported, variously, as collected by De Vis, shot by Macgregor at approximately 2100 m ASL or “obtained through natives” (Longman 1928: 155; Troughton 1971: 94; Koler-Matznick et al. 2007: 48; http://mammals-ofpapua.webs.com/newguineasingingdog.htm, accessed 15 April 2015). Murray (1912: Chapter X1) reported that Macgregor visited Mount Scratchley in 1896 where traces of "dingoes were everywhere", animals were heard "above 10,000 feet" [3000 m] and the only one seen was large and "black". Murray made no reference to animals being shot or collected at this time.

The provenance of the purported "Lavani Valley" animals is uncertain. They were described by Troughton (1957) who wrote that they were obtained in 1956 in "the remote Lavani Valley ... by A.D.O. J. P. Sinclair and Medical Assistant Albert Speer”. Sinclair and Speer undertook a 75 day patrol out from Tari between 10 May 1955 and 10 July 1955. They spent two days in Lavani Valley. Sinclair (1955: 62) wrote that "many very good specimins (sic) of CANINE PAPUENSIS (sic) were seen" in the course of the patrol, with "some particularly fine animals seen in LAVANI Valley". He did not state that the dogs were living as wild animals. Speer (1955) did not refer to dogs in his report. A year later, on 31 May 1956, Speer (1956a) wrote to Sir Edward Hallstrom who, at that time, 
maintained a livestock and fauna station at Nondugl in what is now Jiwaka Province. Speer had in his possession "one of the local native dogs", a male pup about two months old. He offered this to Hallstrom and stated that he might be able to also get a female. At this time Speer was based at a recently opened Patrol Post at Koroba, about $20 \mathrm{~km}$ east of Lavani Valley. By 5 August 1956, the male dog - now a "big dog” named Duna - together with a female pup had been delivered to Nondugl fauna station (Speer 1956b). None of the documentation we have seen establishes the provenance of these two dogs or their status as wild-living or village-bred animals.

Hallstrom donated his pair of dogs to the Taronga Zoological Park in Sydney and, together with a third animal of unknown provenance from the Baiyer River Sanctuary, Papua New Guinea, these were the founding members of the captive population that has been the basis of numerous studies of New Guinea Singing Dogs in the United States of America. The live animals from Eipomek River Valley were the founding members of a population of captive animals held in Germany. They have been described as previously wild-living dogs that were kept by villagers (Koler-Matznick et al. 2007: 49) and as village dogs (Schultze-Westrum 2010a).

Koler-Matznick et al. (2007: 49) acknowledged that the "current captive singing dog population is descended from eight specimens ... not directly caught in the wild". They continued: "This does not mean, however, that these specimens were village $C$. familiaris". Certainly, the probable village-based origin of the first dogs collected from New Guinea does not mean that they were "village C. familiaris". Nor, however, does it mean that other village-based dogs in the source villages or elsewhere in New Guinea were C. familiaris, in the sense that Koler-Matznick and her co-authors intended by this usage, or that they were distinct from dogs that lived as wild animals.

\section{NOMENCLATURE AND RELATIONSHIPS}

In 1879, Ramsay (1879: 242) used the name Canis familiaris var. papuensis for a single specimen of coastal village dog that was received in bad condition and not retained. Apart from noting that the Papuan dogs were "unable to bark, properly so called" and that the "usual height is about 12 to 15 inches", he did not provide a description. MiklouchoMaclay, apparently following and adapting Ramsay, referred to Rai Coast village dogs as Canis papuensis (1881: 625). In 1957, Troughton described the two New Guinea dogs from Taronga Zoological Park - a male holotype and a female allotype - as a new species that he named Canis hallstromi. He stated that the name used by Ramsay is "invalidated as a nomen nudum" (Troughton 1957: 94, 1971).

In later publications New Guinea dogs found at high altitudes have been referred to as Canis familiaris, C. hallstromi, C. f. hallstromi, C. lupus f. familiaris and C. l. dingo (Koler-Matznick et al. 2003: 110). Authors have differed, however, in asserting that wildliving New Guinea dogs are or are not feral, have rarely commented on the taxonomic status of village dogs, past or present, and with few exceptions - notably the contributions of Koler-Matznick and co-authors - failed to justify their assertions. It has been frequently suggested that wild-living New Guinea dogs and dingoes are likely to be closely related, though here too opinions have differed (e.g. Gollan 1984, Corbett 2004). Most recently, Jackson and Groves (2015: 288), urging "caution about applying formal scientific names to introduced populations", consider that the trivial names dingo, papuensis and hallstromi should be treated as synonyms of familiaris. They argue, further, that subspecific labelling within $C$. familiaris is unwarranted on the grounds "of a general acknowledgement that a 
domestic species cannot have subspecies because these could not be geographic segments of the species as they have no natural distribution".

Many recent molecular studies have sought to establish the phylogenetic relationships among breeds of domestic, feral and wild-living dogs and determine the number of times dogs may have originated from wolves (Savolainen et al. 2002; Runstadler et al. 2006; Ardalan et al. 2012; Larson et al. 2012; Sacks et al. 2013). These studies tend to show relatively strong connections between dingoes and New Guinea dogs. With two exceptions, the New Guinea samples were sourced from the captive population. Oskarsson et al. (2012) examined 909 samples of dogs from 12 countries (southeast Asia, New Guinea, Australia and Polynesia). Their New Guinea samples came from three highland dogs - sourced from the US captive population - and 12 lowland village dogs. They reported one haplotype (A79) present in one highland dog and three lowland dogs as unique to New Guinea dogs and as "indicative of a relation" between these populations (pp. 971-972). Shannon et al. (2015: 1) examined "autosomal, mitochondrial, and Y chromosome diversity in 4,676 purebred dogs from 161 breeds and 549 village dogs from 38 countries". Their sample include village dogs from Port Moresby $(\mathrm{n}=9)$ and Eastern Highlands ( $\mathrm{n}=11)$, Papua New Guinea. The ancestry of these animals was closer to that of dogs from Europe than it was to dogs from either Vietnam or Borneo, presumably reflecting hybridization with dogs introduced after European colonization.

\section{BODY FORM AND TAIL BRUSH}

Koler-Matznick et al. (2007: 48) asserted that "even from the earliest accounts, observers of the wild mountain singing dogs commented that these dogs appeared to be a separate type from the New Guinea village dog C. familiaris" and listed De Vis (1911), Longman (1928), Wood-Jones (1929) and Tate (1944) as supporting references. De Vis described a dog from the Mount Scratchley area after a taxidermist had done "his best" working with a single "well macerated skin and separate skeleton". He had no other material from New Guinea but speculated that "so far as I am aware, the present natives of the island possess no tame breed of dog similar to this - none, therefore, from which this could have departed”. Longman examined two skins and skulls from the Mount Scratchley area that were held by the Queensland Museum, reported that they had been "obtained from the natives" and that there was some doubt "as to whether they were really feral" (1928: 155), and had nothing to say regarding a distinction between village and wild-living dogs. Wood-Jones (1929: 331) examined the Mount Scratchley specimens, stated that the animal "differed widely in its characters from the dogs of certain other Pacific islands", but made no specific reference to village dogs from New Guinea. Tate (1944: 16) commented very briefly, without reference to specimens, that most New Guinea dogs "are domesticated and live around native villages. Some, however, appear to be feral. ... These wild dogs are apparently very rare and live high in the mountains". In a later publication Tate (1952: 613-614) examined five dogs from the Indenburg River, at that time in Netherlands New Guinea, wrote that "presumably they were domestic, not wild, animals" and, like De Vis, Longman and Wood-Jones made no reference to differences between wild-living and village New Guinean dogs. Troughton (1957: 93) wrote that "evidently, at least two breeds of dog have been reported from Papua, a vari-coloured lowland form of domesticated dog, and a small dingo-like dog of the extreme highlands". He did not, however, examine specimens from the lowlands, and there is uncertainty regarding the provenance as village or wild-living of the two specimens he did describe. Husson (1955: 6-7) also asserted that Papuan coastal and highlands dogs were distinct but without specific reference to wildliving dogs. 
The references provided by Koler-Matznick et al. (2007) do not support their contention that early reports considered "wild mountain singing dogs" and "the New Guinea village dog" to be separate types, and the comments by Troughton and Husson lack supporting evidence.

Schultze-Westrum $(2010 a, b, c)$ considered that there were "several distinct strains" of New Guinea dogs, provided detail on colour variation and stated that these "should be divided by their appearance into two main groups": a "slim, long-legged type" in the lowlands and a "stocky" type in the highlands and the sub-montane regions. He asserted that in some inland areas, such as Bosavi (500 m ASL and higher), these two types coexisted (2010a: Section 11, Conclusion). He considered that the lowland dogs were "closely linked to the dingo", acknowledged that at these altitudes "interbreeding with recently introduced dogs ... had largely disrupted the endemic strain" and stated that the highland dogs lived as both village and wild animals. Thus, in Schultze-Westrum's judgement, the high altitude wild-living dogs of New Guinea were not a biologically distinct form. As evidenced by quotations included in this paper some reports assert that it is high altitude dogs that are similar to dingoes while others assert that it is low altitude dogs that are similar to dingoes.

Schultze-Westrum considered that in the Mount Bosavi area the "stocky" type of dog was more abundant than the "slim" type, and collected 14 skulls from dogs that had died during a recent epidemic. One of the skulls came from a juvenile individual. Measurements of the other 13 were reported by Boessneck and Meyer-Lemppenau (1969). There was no hint in the sample that two types were represented. Regrettably, SchultzeWestrum did not provide a detailed account of the differences between his two "types" and the photographic evidence provided in support, though suggestive, is not definitive (2010c). Our own tentative judgement, from an examination of those photographs is that dogs of Schultze-Westrum's "stocky type" are more barrel-chested - thicker around shoulders, chest and prosternum - than dogs of his "slim type".

Koler-Matznick et al. (2003: 112) reported that captive New Guinea dogs have a "pale brush" on the underside of the tail like that seen in Australian dingoes. They asserted further that "Papuan village dogs have ... no brush on the underside of the tail" (p. 110). However, several reports refer to the "bushy tail" of coastal village dogs (e.g. Jukes 1847: 269; Goodale 1995: 70), a tail brush is unambiguously present in some photographs of dogs from lowland areas of Gulf and Western Provinces (Schultze-Westrum 2010c: Figs. $17,24,30,41,42)$ and is conspicuous in cases where the tail is raised and arched forward (2010c: Figs. 30, 41, 42). This was true also of the dogs we observed at Gwaimasi and Suabi in the lowlands of Western Province. In some of our photographs a tail brush is conspicuous, in others it is not. In part, this variation may be inherent in the animals themselves. Thus, Koler-Matznick et al. (2005: 5) observed that in captive New Guinea dogs, tails "vary in length, fullness of brush, extent of white tip, amount of forward curve when held above the back, and the presence/absence of sideways or spiral curves". The variation may also arise, in part, because it is only in some contexts that long hairs on the underside of the tail are erected. Fox (1969: 264), for example, has reported that in the grey fox the "immediate reaction to live prey" entailed approach with "tail arched in an inverted $U$ and the hair erect”. In this species, he considered piloerection of the arched tail to be an autonomic reaction to prey (p. 269). 


\section{COLOUR AND PATTERN}

Koler-Matznick et al. (2003: 110) report captive New Guinea dogs as being "brown; black with tan on muzzle, legs, vent; sable" and further refine the description of "brown" as "pale brown, ginger, or russet counter-shaded with lighter shades on belly, inner surfaces of legs, and ventral brush of tail". Dogs "usually have white on underside of chin, paws, chest, and tail tip" and "about one-third also have white on muzzle, face, and neck". Photographs in Koler-Matznick et al. (2005) show that areas of white across the nape, shoulders and upper back may be extensive. They wrote that wild-living animals have been described as "brown, black with tan, or black, all with white points". SchultzeWestrum (2010a: Section 9) reported that:

most of the 31 individuals reared (up to 1968) in the Institut für Haustierkunde, Kiel, had a brown coat colouration in different shades and with white markings, on the feet and in the face, but sometimes also a white patch on the neck. 10 were black with white markings.

Majnep considered that wild-living dogs in the Schrader Range could be "white, black, dull brown, or pied, partly white and partly black, just as we have among domestic dogs” (Majnep and Bulmer 2006: 289). This range of colours and patterns is consistent with Crowther et al.'s (2014) report of the wide variation found in $19^{\text {th }}$ Century specimens of dingoes. They advised against the use of pelage criteria to diagnose dingoes.

A comparable range of colours and patterns has been reported for village dogs from New Guinea in both early and later literature. In May 1845, Jukes (1847: 268-269) observed dogs at a location to the north-east of the mouth of the Fly River. He wrote: "Several of them were white, or white patched with brown; but others were of a reddish brown all over, with sharp snout, bushy tail, rather small body, and erect ears, precisely like the dingo". In Rawling's (1913: 124) report of an expedition into the interior of western Netherlands New Guinea he noted that: "The dogs are of the usual yellow mongrel type, about the size of an Irish terrier". Majnep wrote that in the Schrader Range, village "dogs can be black, dull grey-brown, white or reddish-brown; and some are multicoloured” (Majnep and Bulmer 2006: 273). In the Mount Bosavi area, village dogs that Schultze-Westrum (2010a: Section 10) judged to be stocky "varied from light to darker brown with white and blackish marks, to all black with some white markings ... [w]ith a white tip on the tail" and those he judged to be slim were "fawn to reddish brown" ... with "blackish face markings" and "again a white tip on the tail".

In the years 1986-1999 the dogs that were resident at Gwaimasi, on the Strickland River, and those that arrived with visitors, were of the order of 10-12 kg (adult weight), of very uniform body shape but variable in colour and markings. In our retrospective judgement the healthiest among them - many were gaunt - would be more likely to fit into Schultze-Westrum's "stocky" category, rather than his "slim" category. Figure 1 records the colours and markings of nine dogs sketched in December 1986. Two colours predominated - black and an orange-brown that verged on ginger (Fig. 2a,b) - but on all animals there were spots or areas of white or, where black predominated, of orange-brown. For example, small patches of orange-brown were present on the faces and chests of Dogs 1 and 2 (Fig. 1). In a few dogs the areas of white were extensive (Dogs 4 and 6). All the dogs that were sketched had white tipped tails and white "socks" though the extent of the white varied between animals. Photographs reveal that in many of the dogs the underside of the tail was near-white for much of its length (Fig. 2a). 




Fig. 1: Field sketches of colour and markings on nine dogs at Gwaimasi village in mid-December 1986. $\mathrm{M}=$ male; $\mathrm{F}=$ female; arrows point to small patches of white. Faithful rendering of colour was limited by available tools but No. 5 was pale (and emaciated) relative to Nos. 1 and 2. 

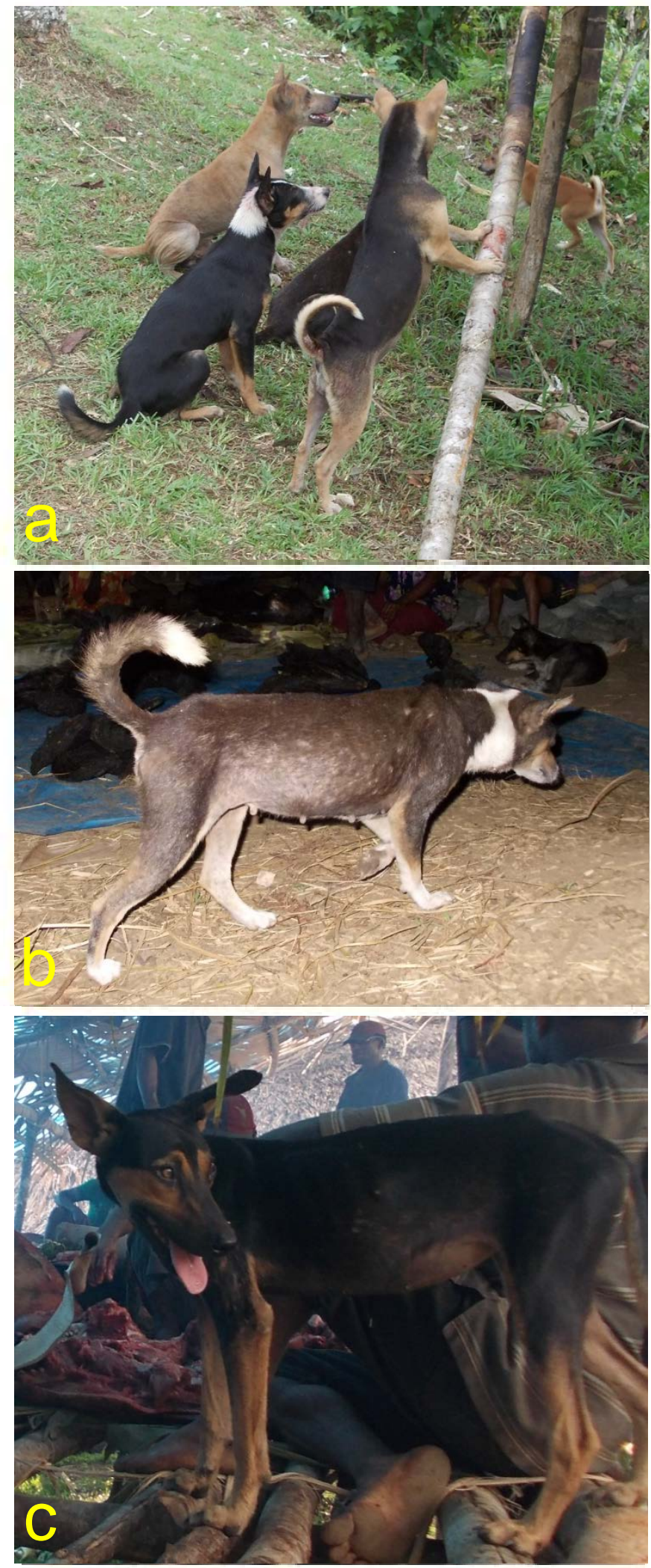

Fig. 2: $a$, Dogs at base of rack on which a pig is being butchered; $b$, pregnant female, tail flagging and revealing brush on tail; $c$, young dog named "Kiunga" after the town from which it was acquired as a pup. In this dog the muzzle is narrow and pointed and the tail (partly obscured) is relatively long, thin and without a brush. Photographs taken at Suabi in 2012, P. D. Dwyer. 
In size, form and colour the dogs seen at Suabi in the years 2011 to 2014 were more diverse than those present at Gwaimasi in earlier years. In the intervening period people had acquired pups from distant places when they, or their kin, had travelled and, being interested in and curious about animals, had biased their acquisitions for dogs that looked different; dogs with genealogical connections to introduced breeds (Fig. 2c). But many of the dogs were of the size, form and colours seen in 1986-87 (Fig. 2a,b).

On the basis of available information, both past and recent, about colour and pattern it is not possible to distinguish wild-living dogs from village dogs in New Guinea.

\section{DISTRIBUTION AND REPRODUCTIVE ISOLATION}

Early reports of wild dogs in New Guinea influenced an understanding that it would be only in remote high altitude areas, above the level of human residence, that viable populations which had not hybridized with introduced dogs might persist (Troughton 1971: 93; Koler-Matznick et al. 2003: 114). However, if the Mount Scratchley specimens were collected at about $2100 \mathrm{~m}$ ASL then they were within a few kilometres of a moderately well populated area of Fuyuye-speakers (Bradshaw 2007: 1). The Lavani Valley and the Eipomek River valley were also well populated in, respectively, the 1950s and 1970s (Anon 1954; Speer 1955; Schiefenhövel 2014: 249). Thus, the sites from which early specimens of New Guinea dogs were sourced were remote only from the perspective of European outsiders. Indeed, in the 1950s, the Lavani Valley was popularly romanticized as Papua New Guinea's "Shangri-La” (Simpson 1954; Troughton 1957: 93) and was referred to by this name by Clyde Hill when discussing the source of animals held by the San Diego Zoo (Koler-Matznick et al. 2007: 49).

Koler-Matznick et al. (2007: 52) suggested that wild dogs were present in the altitude range 2500-4700 m ASL and commented specifically on "the former and continuing geographic isolation of the singing dogs from other canids in the high elevation New Guinea mountains” (p. 49; see also Wobber et al. 2009: 209). Though domestic dogs have been reported in highland villages to 2000 m ASL (e.g. Heider 1970: 57; Waddell 1972: 60), Koler-Matznick and co-authors asserted that New Guinea village dogs are "adapted to a tropical climate and would therefore have a difficult time surviving for any significant period in a Highland village, let alone in the ... altitudes where wild singing dogs range” (2007: 52). Brisbin et al. (1994: 35-36) reported possible high altitude locations on the basis of vocalizations, Hope (1976: 221-222) reported that wild-living dogs were common at high altitudes (to $4300 \mathrm{~m}$ ASL) in the Mount Jaya region (Irian Jaya) and, in the late 1980s, Flannery (1990: 33, 1998: 173) heard dogs howling and saw and photographed a dog at about $3200 \mathrm{~m}$ ASL in the Star Mountains. Wild-living dogs, however, have been reported to anthropologists from lower altitudes. For example, in the foothills of the Schrader Range in Madang Province wild-living dogs were reported to be present in the altitude zone 1500-1900 m ASL and higher (Majnep and Bulmer 2006: 341). Healey (1990: 185), writing of the neighbouring Kundagai Maring (Jimi Valley), reported that "wild dogs are allegedly common" in forests near the settlement of Tsuwenkai, 1689 m ASL, and "sometimes breed with domestic bitches". At Mount Sisa, about $50 \mathrm{~km}$ southeast of Lavani Valley, Etolo people said that wild-living dogs had been present in undisturbed forest at altitudes as low as $1200 \mathrm{~m}$ ASL to about 1970 (Dwyer 1990: 71). Goodale (1995: 70) reported that, in the 1960s, wild-living dogs were abundant in the mountains of West New Britain Province (500-800 m ASL), that all village-based male dogs were castrated by Kaulong people and that village-based bitches were impregnated by wild dogs. She described the dogs as "small and terrierlike, with pointed ears, bushy tails, and short coats of varied colors" and recalled "the wolflike howling of the village 
dogs taken up by their wild cousins, the sound echoing back and forth, and then the sudden silence". Dogs living as wild animals have been also reported from low altitude savannahs of the extreme southwest of Papua New Guinea in myths recorded in the early 1900s and from more recent observations in the Tonda Wildlife Management Area though there is little likelihood that these animals were or are reproductively isolated from village dogs (Kwapena 1977: 293; Eaton 1991: 72; Lawrence 2010: 75-76).

The suggestion that dogs kept by New Guinea highlanders derived from wildliving animals and were not bred in captivity (Bulmer 2001: 194; Koler-Matznick et al. 2007) is not supported by the detailed account of Majnep (Majnep and Bulmer 2006). The observations summarized above challenge assertions that wild-living dogs were found only above the limit of human habitation and were reproductively isolated from village dogs. Koler-Matznick et al. (2007: 53) suggested that wild-living dogs found at high altitudes "may be at least partially descended from wild singing dogs that in the past occupied the Lowlands before that habitat was turned into agricultural land". However, vast areas of lowland New Guinea - some now subject to extensive logging - have never been "turned into agricultural land" and, thus, in itself, this cannot provide a rationale for the disappearance of wild-living dogs, if they existed there, from much of the lowlands.

\section{LOCAL KNOWLEDGE}

Koler-Matznick et al. (2007: 49) wrote that "the Highlander's particular knowledge of and regard for these distinctive canids must be considered when contemplating the origin of the captive population". They commented that "in all local informant reports to date, the New Guinea Highland wild dog has a different local name than the village C. familiaris". This is unsurprising, because habitat is often prominent in informing the distinctions New Guineans make between kinds of animals and the nomenclature they apply to those animals (Dwyer 1976a,b). In the Strickland Plains region, for example, domestic and wild pigs have different names. Thus, Etolo people name domestic pigs sugua foi, and wild pigs segeligi (or sugua segeligi), Bedamuni name domestic pigs kebo and wild pigs sigua (or sigua kebo), and Kubo name domestic pigs o wai and wild pigs o foi. In the Bedamuni and Kubo cases the fathers of all domestic pigs are wild boars (Dwyer 1996). Neither with pigs, nor with dogs, do these nomenclatural distinctions carry any implication that the village and wild-living animals are taxonomically distinct from the perspective of zoological science.

In 1996 James McIntyre spent four weeks at around 1800 m ASL on Mount Stolle in the Star Mountains. He was searching for "singing dogs" and though he heard a dog howling he did not see one. He commented, however, that village dogs at 1200-1300 m were predominantly black with white markings, included some with bushy tails and "had remarkable similarities and vocalizations to [those] of the highland wild dog" (McIntyre n.d., 1996). He stated also that "villagers clearly differentiate between village dogs and the wild dogs that live in the upper elevations" but without indicating whether their differentiation was based on anything other than their knowledge of geographic location, habitat and mode of life (n.d.).

Koler-Matznick et al. (2007: 51) asserted that "The original practice of many of the Highland peoples was to capture wild singing dog puppies (most often only males) and raise them as hunting aids". They wrote that "singing dogs were highly valued by Highland hunters because they helped to increase the products of the hunt several times over”. Here they drew on reports by R. Bulmer as interpreted by S, Bulmer (2001). In fact, in R. Bulmer's early writing, he noted that the "dog of the interior is sometimes known as 
Canis familiaris hallstromi or C. hallstromi" and commented that "pre-European domestic dogs in much of interior New Guinea were certainly extremely similar in appearance and behaviour to feral populations" (Bulmer 1968: 307). He wrote also that village dogs were "said to interbreed with feral stock" and that "pups of feral bitches are sometimes captured and kept as domestic animals" (Bulmer and Menzies 1972: 486). On the basis of R, Bulmer's later work, with Majnep, it is clear that Kalam people maintained a breeding population of village dogs with minimal input from captured wild-living males (Majnep and Bulmer 2006). Thus, Majnep introduced his account of wild-living dogs with the words (in translation): "wild dogs look like ordinary domestic dogs" (2006: 289) and commented that the former are not often seen but he had known one that had been acquired as a "wild dog puppy" (p. 289). The writings of R. Bulmer and Majnep do not imply the existence of wild-living dogs that are reproductively isolated from village dogs in New Guinea.

\section{BEHAVIOUR}

\section{Vocalizations}

Koler-Matznick et al. (2005: 42-44) describe the vocal behaviour of captive New Guinea dogs, purportedly derived from wild-living animals, as "very complex" and as including "short explosive barks", growls, howls and chorus howls, moans, screams, trills, whines and yelps. Howls, chorus howls and trills are regarded as distinctive (Koler-Matznick et al. (2003: 113-114) and barks are said to differ significantly from those of "domestic dogs" in having "lower intensity" and being "produced in single pulses of temporally disorganized sequences rather than a well defined rhythmic series" (2005: 42). The iconic vocalizations are, of course, the howl and chorus howl. It is these vocalizations - "an extraordinary and haunting sound" (Flannery 1990: 32) - that have given the name 'singing dog' to animals thought to live as wild populations. Ortolani et al. (2001: 90) reported that the howling vocalizations of "timber wolves (Canis lupus), coyotes ( $C$. latrans), Australian dingoes (C. dingo), New Guinea singing dogs (C. hallstromi) and domestic dogs (C. familiaris)" were "qualitatively distinct" with "dingo and NGSD howls [showing] the greatest frequency modulation compared to the other canids".

Howling and chorus howling have been reported from the earliest European encounters with coastal and inland village dogs in New Guinea. For example, from a location to the north-east of the mouth of the Fly River, in May 1845, Jukes reported that:

"There was a great howling in the village, which we at first took for that of women and children, but afterwards discovered to be the native dog" and added, as a footnote, "These we could see with our glasses, and they resembled, both in appearance and cry, the dingo or native dog of Australia." (1847: 268-269).

In his Annual Report of 1891-92, William Macgregor, then Governor of British New Guinea, wrote that:

the native dog is everywhere kept as a pet, as an article of diet, or for hunting. The native dog, closely resembling the Australian dingo in appearance, has a strong gregarious tendency. The dogs of a village meet, as a rule, several times a day to howl in chorus - they have not learned to bark - and they hardly ever separate without fighting. They possess remarkably sharp, slender, canine teeth, with which they inflict a deep "snappy” bite (1892-93: x). 
Macgregor was concerned that if rabies should enter the country it "would spread like wildfire".

In Rawling's (1913: 124) report of an expedition into the interior of western Netherlands New Guinea he wrote that:

Curiously enough [the dogs] never bark, but amply make up for any inability to relieve their feelings in this respect by their mournful and prolonged howls. Started by one dog, the identical note is taken up by every animal within hearing distance, and is continued until one wishes every creature dead and buried.

The fact that village dogs in lowland communities howl, rather than bark, was also mentioned by, among others, Mikloucho-Maclay in his Rai Coast diaries of 1871-1883 (1975: 23, 42, 127, 158, 178), Bauerlen in his account of the 1885 expedition to the Strickland River in what was then British New Guinea (1886: 29) and Crandall (1931: 45) in his account of a zoological expedition to the foothills of the Owen Stanley Range. Mikloucho-Maclay considered that the "weeping and wailing" of mourning women was "very similar to the howling of the local dogs" (1975: 178). Additional reports of howling dogs from different parts of New Guinea are provided by Schultze-Westrum (2010a: Section 10).

From inland and highland communities several ethnographic reports comment on village dogs and stress either or both their similarity to dingoes or their frequent howling. Thus, for example, Clarke (1971: 87) wrote that "the Bomagai-Angoing [Madang Province] dogs strongly resemble, at least superficially, the New Guinea 'wild dogs' that I saw on display in the Sydney zoo", Heider (1970: 57) noted that in 1961 all the dogs kept by Dani people "were of a distinctive barkless type whose howling at night sounded like the crying of a woman or child", Hatanaka and Bragge (1973: 56) reported that the dogs kept by Saiyolof of the Om-Lagaip area "are similar to a dingo of Australia, but much smaller" and Whitehead (2000: 89) writing of Seltaman, of the Mountain Ok area, commented that "wild dogs ... are of the same race as the tiny dingo-like animal that makes its home with Central Mountain villagers ... but the wild ones are now scarce ... probably as a result of introduced distemper".

Majnep wrote that, in the upper Kaironk Valley, "in both the early morning and the late afternoon [wild dogs] can be heard yelping and howling” (Majnep and Bulmer 2006: 291). He wrote of two types: "one that's found up in the beeches and the other forests and that's actually seen by men, women and children" and another "that's in the various sacred groves ... which is referred to as 'dog-spirit' and is only actually seen in dreams" (p. 296). The dog-spirit, Majnep wrote, may be "heard after dark, howling in the ancestral groves" (p. 296). And he referred to village dogs that "yap" or "yelp" in contexts of hunting but did not mention either "howling" or "barking".

At Gwaimasi, on the Strickland River, in the years 1986-1999, vocalizations of village dogs included, at least, whines, growls, short sharp barks and howls. Very frequently, when one dog howled many others did likewise. The resultant chorus could be heard from distances greater than a kilometre from the village. A common stimulus for howling, and chorusing, was the departure of one or more people, unaccompanied by dogs, from the village. Sandrine Lefort (pers. comm.) observed the same behaviour in 2014 among dogs at the Fasu village of Haivaro (60 m ASL) in Gulf Province, and Williams (1924: 27), writing of people of the Purari Delta, reported that "apparently the native dog cannot bark, but numbers will howl together, especially in the morning, when the canoes 
go out and they are left behind”. At Suabi, in the years 2011 to 2012, dogs howled and chorused but did so less frequently than in earlier years at Gwaimasi.

\section{Tail Flagging}

Koler-Matznick et al. (2005) writing of captive animals of purportedly wild-type describe behaviour that they name "tail flagging". They wrote:

Often when TROTTING or CANTERING in natural cover, the tail is held above the level of the back waving passively with the motion of the footfalls. This has the effect of prominently displaying the pale brush of the underside of the tail and may help individual NGSDs [New Guinea Singing Dogs] keep visual contact with each other (2005: 12).

And

When hunting, NGSDs may, upon sensing prey, arch the tail upwards and forwards over the back either holding it still or HIGH WAGGING, thus prominently displaying the light colored fluffy brush on the underside of the tail (2005: 14).

Tail flagging - with the tail held erect and, to varying extents, arched forwards occurs in a number of canids, including wolves, coyotes, foxes, dingoes and some breeds of domestic dogs. Interestingly, tail flagging is shown on camp dingoes in some of the paintings by Dick Goobalathaldin Roughsey - 'Marnbill and Gin Gin Making Fish Trap', 'The Travels of Marnbil', 'Trezise and Roughsey searching for Hells Gate Laura' and 'Goobalathaldin's Birthday' - and in some Australian rock paintings of dingoes (e.g. at Bunjil's Shelter, Grampians National Park). It is variously considered to be associated with general attentiveness, aggression, dominance, play bowing, prey killing and, in females, pre-copulatory behaviour (Fox 1969; Bekoff and Diamond 1976; Bekoff 1977, Fig. 1; Corbett 1988: 179; Corbett 1995: 94, Plates 15, 17;

http://runningwiththewolves.org/Behavior2.htm, accessed 16 April 2015).

Tail flagging is seen in some photographs provided by Schultze-Westrum (2010c: Figs. 30, 41-44, 56) of village dogs from the Papuan Gulf, Bosavi and the upper Sepik River. At Gwaimasi, on the Strickland River, tail flagging was so common that we are unable to specify particular contexts in which it was elicited. It was seen in pups, in dogs on their own and in dogs in groups. For example, Figure 3 shows 19 dogs rummaging in the debris left behind after an oven had been opened and the cooked pig, fern and sago had been removed. The dogs are attentive to the remains in the oven and not to one another. In all but two of the three smallest dogs the tail is erect and in 14 of these it is arched over the back. In another photo six males are moving away from a bitch after copulation; in five of the males the tail is erect and arched forward. Tail flagging was common among dogs at Suabi, though there were some animals, apparently derived from outside sources, in which it was not seen (Fig. 2c). 


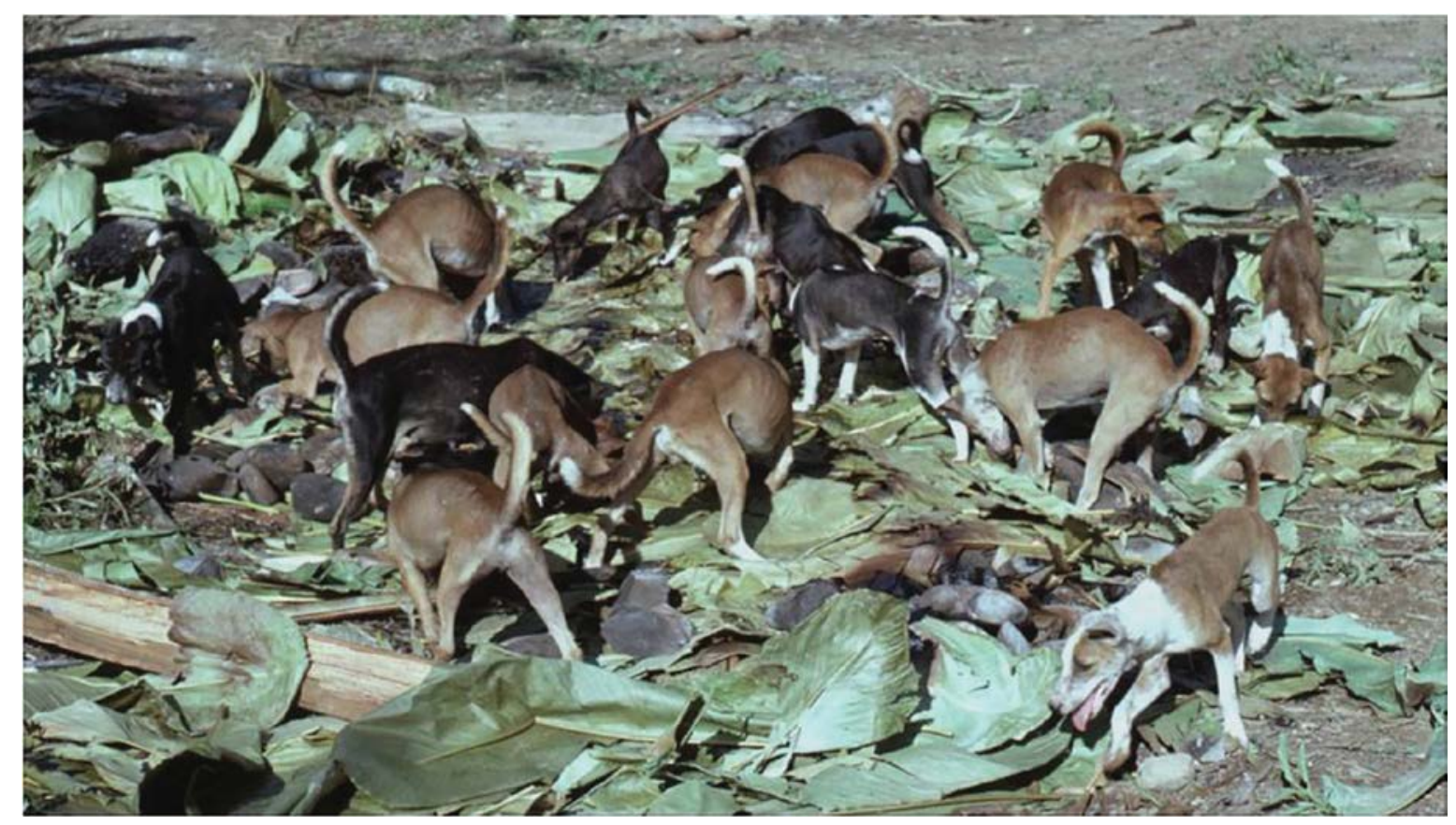

Fig. 3: Dogs rummaging in the debris left behind after cooked food, including pig, has been removed from an oven. Photograph taken at Gwaimasi in 1987, P. D. Dwyer.

\section{Climbing Ability}

Koler-Matznick et al. (2005: 11-12) report that animals in the captive population are adept at climbing. They describe the feet as being "extremely flexible" and able to "curve to grasp objects" and write that the dogs "seem to be especially attracted to bushes when hunting and climb up into any large enough to hold their weight if they spot prey in them". They suggest that the New Guinea dogs have "greater joint elasticity than wolves and [domestic dogs], especially in the neck and spine, and relatively more motion, both rotational and abductional, in the hip joint” (p. 44).

Schultze-Westrum (2010a: Section 10; 2010c: Figs. 54, 55-58) reported that, at Bosavi, village dogs "were very skilled in climbing up ladders to the platforms of houses on stilts". At both Gwaimasi and Suabi village dogs often climbed rough ladders or poles to enter houses or join men and youths who were butchering pigs on high-set racks.

With respect to vocalizations, tail flagging and climbing ability, there are no data to suggest village dogs and wild-living dogs in New Guinea differ in these behaviours. Some behaviours have been reported to be unique to captive New Guinea dogs (e.g. head toss, cheek rub, tooth gnashing, auto erotic stimulation, playful forward summersault, hind foot kick wrestling in puppies; Koler-Matznick et al. 2005: 5) but there is no specific information concerning their presence or absence in any New Guinea village dogs. Mythological tales told by some people, however, highlight the distasteful copulatory behaviour or genital licking of village dogs (Feld 1988; Dwyer 1990: 21-22; Majnep and Bulmer 2006: 301-305) and it is not uncommon that people are disparaged for sexual behaviour like that of dogs (e.g. Counts and Counts 1991; Wardlow 2004: 1035-1036).

\section{CONCLUSION}

In early reports from coastal lowland New Guinea, at Bosavi in 1966, at Gwaimasi in 1986-87 and to a lesser extent at Suabi in 2011-14 most village-based dogs corresponded in a number of morphological and behavioural attributes to features that have been 
highlighted in accounts of high altitude, purportedly wild-living, New Guinea dogs. These include size, colour and markings, the presence of a tail brush, tail flagging, climbing ability, howling and chorusing. None of these attributes distinguishes village dogs at any altitude of New Guinea from wild-living dogs though they are suggestive of, at least, a quantitative difference between pre-colonization New Guinea dogs and many breeds of $C$. familiaris; quantitative in the sense that, while neither universal nor commonplace, the behavioural attributes may be exhibited by some breeds. For example, Alsatians may howl and chorus (https://www.youtube.com/watch?v=91Ylx-8j-aQ, accessed 20 April 2015) and, among others, the Japanese breeds Akita and Shikoku may carry their tails high and forward, displaying a prominent brush (http:/www.dogguide.net/breed-a.php; http://en.wikipedia.org/wiki/Shikoku_\%28dog\%29, accessed 20 April 2014).

At this time, therefore, there is no convincing evidence that New Guinea wildliving dogs and some, or all, pre-colonization New Guinea village dogs were distinct forms. Further, there is no definitive evidence that either high altitude wild-living dogs were formerly isolated from other New Guinea canids or that the animals that were the founding members of captive populations of New Guinea Singing Dogs were wild-living animals or the progeny of wild-living animals rather than being born and raised as members of village populations of domestic dogs.

We conclude that: (1) at the time of European colonization, wild dogs and most, if not all, village dogs of New Guinea comprised a single though heterogeneous gene pool' (2) eventual resolution of the phylogenetic relationships of New Guinea wild dogs will apply equally to all or most of the earliest New Guinea village-based, domesticated, dogs; and (3) there remain places in New Guinea, such as Suabi and neighbouring communities, where the local village-based population of domestic dogs continues to be dominated by individuals whose genetic inheritance can be traced to pre-colonization canid forebears. We are unable to comment usefully on Shultz-Westrum's (2010a) opinion that lowland and highland New Guinea dogs, the latter including wild animals, qualified as distinct breeds. We note, however, Bulmer's (2001: 197) opinion that, prior to European colonization, dogs may have reached New Guinea more than once and as more than one type and, further, that there is no certain archaeological record of dogs in New Guinea sites before about 1500 years ago (Sutton et al. 2009: 53). None of these matters may be definitively resolved by observational studies of village, wild or captive populations of New Guinea dogs. They may be resolved, however, by further genetic studies from appropriate locations in New Guinea. At this time there is no firm basis from which to assign a unique Linnaean name to dogs that live as wild animals at high altitudes of New Guinea.

\section{ACKNOWLEDGEMENTS}

We thank Chris Ballard, Barry Craig, Éloïse Déaux, Robin Hide, Janice Koler-Matznick, Sandrine Lefort, Peter Ogilvie, Alessia Ortolani, Jeffrey Willmer, two anonymous referees and the people of Gwaimasi and Suabi villages for assistance. Our research in Papua New Guinea has been supported, at different times, by periods of leave granted by The University of Queensland and The University of Melbourne and by grants from the Papua New Guinea Biological Foundation and the Australian Research Council. 


\section{REFERENCES}

Anon (1954). Into the lost world. The Courier-Mail, 21 September 1954, p. 2.

Ardalan, A., Oskarsson, M., Natanaelsson, C., Wilton, A. N., Ahmadian, A. and Savolainen, P. (2012). Narrow genetic basis for the Australian dingo confirmed through analysis of paternal ancestry. Genetica 140, 65-73.

Bauerlen, W. (1886). 'The Voyage of the Bonito: An Account of the Fly River Expedition to New Guinea.' (Gibbs, Shallard: London.)

Bekoff, M. (1977). Social communication in canids: evidence for the evolution of a stereotyped mammalian display. Science 197, 1097-1099.

Bekoff, M., and Diamond, J. (1976). Precopulatory and copulatory behavior in coyotes. Journal of Mammalogy 57, 372-375.

Bino, R. (1996). Notes on the behaviour of the New Guinea Singing Dog (Canis lupus dingo). Science in New Guinea 22, 43-47.

Boessneck, J., and Meyer-Lemppenau, U. (1969). Eine sammlung von hundensch ädlen aus Papualand. Säugetierkundliche Mitteilungen 17, 356-368.

Bradshaw, R. L. (2007). Fuyug grammar sketch. Data Papers on Papua New Guinea Languages, Volume 53. SIL-PNG Academic Publications, Ukarumpa, Papua New Guinea.

Brisbin, I. L. Jr, Coppinger, R.P., Feinstein, M. H., and Austad, S. N. (1994). The New Guinea Singing Dog: taxonomy, captive studies and conservation priorities. Science in New Guinea 20, 27-38.

Bulmer, R. N. H. (1968) The strategies of hunting in New Guinea. Oceania 38: 302-318.

Bulmer, R. N. H., and Menzies, J. I. (1972). Karam classification of marsupials and rodents. Journal of the Polynesian Society 82, 86-107.

Bulmer, S. (2001). Lapita dogs and singing dogs and the history of the dog in New Guinea. In 'The Archaeology of Lapita dispersal in Oceania'. (Eds. G. R. Clark, A. J. Anderson and T. Vunidilo.) Pp. 183-201. (Australia: Pandanus Books: Canberra.)

Clarke, W. C. (1971). 'Place and People: An Ecology of a New Guinean Community.' (ANU Press: Canberra.)

Corbett, L. K. (1988). Social dynamics of a captive dingo pack: population regulation by dominant female infanticide. Ethology 78, 177-198.

Corbett, L. K. (1995). 'The Dingo: In Australia and Asia.' (University of New South Wales Press: Sydney.)

Corbett, L. K. (2004). The New Guinea singing dog - unique, dingo or hybrid? Abstract, Australian Mammal Society Scientific Conference 2004. Australian Mammal Society Newsletter, October 2004.

Crowther, M. S., Fillios, I. M., Colman, N. and Letnic, M. (2014). An updated description of the Australian dingo (Canis dingo Meyer, 1793). Journal of Zoology 293, 192203.

Counts, D. E., and Counts, D. R. (1991). 'People who act like dogs:' adultery and deviance in a Melanesian community. Anthropologica 33, 99-110. 
Crandall, L. S. (1931). 'Paradise Quest: A Naturalist's Experiences in New Guinea.' (Charles Scribner's Sons: New York.)

De Vis, C. W. (1911). A wild dog from British New Guinea. Annals of the Queensland Museum 10, 19-20.

Dwyer, P. D. (1976a). Beetles, butterflies and bats: species transformation in a New Guinea folk classification. Oceania 46, 188-205.

Dwyer, P. D. (1976b). An analysis of Rofaifo mammal taxonomy. American Ethnologist 3, 425-445.

Dwyer, P. D. (1990). 'The Pigs that Ate the Garden: A Human Ecology from Papua New Guinea.' (University of Michigan Press: Ann Arbor.)

Dwyer, P. D. (1996). Boars, barrows and breeders: the reproductive status of domestic pig populations in mainland New Guinea. Journal of Anthropological Research 52, 481500 .

Dwyer, P. D., and Minnegal, M. (1991). Hunting in lowland tropical rainforest: towards a model of non-agricultural subsistence. Human Ecology 19, 187-212.

Dwyer, P. D., and Minnegal, M. (1992a). Ecology and community dynamics of Kubo people in the tropical lowlands of Papua New Guinea. Human Ecology 20, 21-55.

Dwyer, P. D., and Minnegal, M. (1992b). Cassowaries, chickens and change: animal domestication by Kubo of Papua New Guinea. Journal of the Polynesian Society 101, 373-385.

Dwyer, P. D., and Minnegal, M. (2014). Where all the rivers flow west: maps, abstraction and change in the Papua New Guinea lowlands. The Australian Journal of Anthropology 25, 37-53.

Eaton, P. (1991). Wetland management - traditional rights and recreational uses: the Tonda wildlife management area of Papua New Guinea. Landscape and Urban Planning 20, 67-72.

Feld, S. (1998). They repeatedly lick their own things. Critical Inquiry 24, 445-472.

Flannery, T. F. (1990). 'Mammals of New Guinea.' (Robert Brown and Associates: Carina, Queensland.)

Flannery, T. (1998). ‘Throwim Way Leg: An Adventure’. (Text Publishing: Melbourne.)

Fox, M. W. (1969). Ontogeny of prey-killing behavior in Canidae. Behavior 35, 260-272.

Gollan, K. (1984). The Australian Dingo: in the shadow of man. In 'Vertebrate Zoogeography and Evolution in Australasia’. (Eds. M. Archer and G. Clayton.) Pp. 321-327. (Carlisle, W.A, Hesperian Press.)

Goodale, J. C. (1995). 'To Sing with Pigs is Human: The Concept of Person in Papua New Guinea’. (University of Washington Press: Seattle.)

Hatanaka, S., and Bragge, L. W. (1973). Habitat, isolation and subsistence economy in the Central Range of New Guinea. Oceania 44, 38-57.

Healey, C. (1990). 'Maring Hunters and Traders: Production and Exchange in the Papua New Guinea Highlands.' (University of California Press: Los Angeles.)

Heider, K. G. (1970). 'The Dugum Dani: A Papuan Culture in the Highlands of West New Guinea.' (Aldine Publishing Company: Chicago.) 
Hope, J. H. (1976). Fauna. In 'The equatorial glaciers of New Guinea'. (Eds. G. S. Hope, J. A. Peterson and I. Allison.) Pp. 207-234. A. A. Balkerma: Rotterdam.)

Husson, A. M. (1955). Tabel voor het determineren van de land-zoogdieren van Nederlands Nieuw-Guinea. Zoologische Bijdragen 1, 1-35.

Jackson, S., and Groves, C. (2015). 'Taxonomy of Australian Mammals.' (Clayton South, Victoria, CSIRO Publishing.)

Jukes, J. B. (1847). 'Narrative of the Surveying Voyage of H.M.S. Fly, Commanded by Captain F.P. Blackwood, R.N., in Torres Strait, New Guinea, and Other Islands of the Eastern Archipelago, During the Years 1842-1846: Together with an Excursion into the Interior of the Eastern Part of Java. Volume 1.' (T. \& W. Boone: London.)

Koler-Matznick, J., Brisbin, I. L. Jr., and Feinstein, M. (2005). An Ethogram for the New Guinea Singing (Wild) Dog (Canis hallstromi), 3/2005. (The New Guinea Singing Dog Conservation Society, U.S.A.)

Koler-Matznick, J., Brisbin, I. L. Jr., Feinstein, M., and Bulmer, S. (2003). An expanded description of the New Guinea Singing Dog (Canis hallstromi Troughton, 1957). Journal of Zoology 261, 109-118.

Koler-Matznick, J, Yates, B. C., S. Bulmer, S., and Brisbin, I. L. Jr. (2007). The New Guinea singing dog: its status and scientific importance. Australian Mammalogy 29, 47-56.

Kwapena, N. (1977). Wildlife and habitat management in Papua New Guinea. In 'The Melanesian Environment’. (Ed. J. H. Winslow.) Pp. 293-302. (Angus and Robertson (S. E. Asia): Singapore.)

Larson, G., Karlsson, E. K., Perria, A., Webster, M. T., Hoe, S. Y. W., Peters, J., Stahl, P. W., Piper, P. J., Lingaas, F., Fredholm, M., Comstock, K. E., Modianom, J. F., Schellingo, C., Agoulnikp, A. I., Leegwater, P. A., Dobney, K., Vigne, J-D., Vilà, C., Anderssond, L., and Lindblad-Toh. K. (2012). Rethinking dog domestication by integrating genetics, archeology, and biogeography. Proceedings of the National Academy of Sciences 109, 8878-8883.

Lawrence, D. (2010). 'Gunnar Landtman in Papua 1910 to 1912.' (ANU E Press: Canberra.)

Longman, H. A. (1928). Notes on the dingo, the Indian wild dog, and the Papuan dog. Memoirs of the Queensland Museum 9, 151-157.

Macgregor, W. M. (1892-3). 'Annual Report, British New Guinea, from $1^{\text {st }}$ July, 1891 to 30 June, 1892.' (Government Printer: Brisbane.)

Majnep, I. S. and Bulmer, R. (1977). 'Birds of My Kalam Country.' (Auckland University Press: Auckland.)

Majnep, S. I., and Bulmer, R. (2006). 'Animals the Ancestors Hunted: An Account of the Wild Mammals of the Kalam area, Papua New Guinea.' (Crawford House: Adelaide.)

McIntyre, J. (n.d.) 'My 1996 one man adventure looking for wild singers.' Available at http://newguinea-singing-dog-conservation.org/Tidbits/McIntyre.pdf [accessed 9 April 2015]. 
McIntyre, J. M. (1996). Investigation into the status and conservation needs of the freeliving New Guinea Singing Dog (Canis lupus dingo) 1996. Available at http://vanuatu.tripod.com/dogs.htm [accessed 3 October 2015].

Miklouho-Maclay, N. De (1881). Remarks about the circumvolutions of the cerebrum of Canis dingo. Proceedings of the Linnean Society of New South Wales 6, 624-626.

Mikloucho-Maclay (1975). 'New Guinea Diaries 1871-1883.' (Translated from the Russian with biographical comments by C.L. Sentinella.) (Kristen Pres: Madang, P. N. G.

Murray, J. H. P. (1912). 'Papua or British New Guinea.' (T. Fisher Unwin: London.)

Ortolani, A. A., Corbett, L. K., Feinstein, M. H. and Coppinger, R. P. (2001). A comparative study of larynx anatomy and howling vocalizations in five canids. Canid Biology and Conservation Conference, Programme \& Abstracts, Oxford, UK, September 17-21.

Oskarsson, M. C. R., Klütsch, C. F. C., Boonyaprakob, U., Wilton, A., Tanabe, Y., and Savolainen, P. (2012). Mitochondrial DNA data indicate an introduction through mainland Southeast Asia for Australian dingoes and Polynesian domestic dogs. Proceedings of the Royal Society B, 279, 967-974.

Ramsay, E. P. (1879). Contributions to the zoology of New Guinea. Parts I and II. Proceedings of the Linnean Society of New South Wales 3, 241-305.

Rawling, C.G. (1913). 'The Land of the New Guinea Pygmies: An Account of the Story of a Pioneer Journey of Exploration into the Heart of New Guinea.' (Seeby Service: London.)

Runstadler, J. A., Angles, J. M., and Pedersen, N. C. (2006). Dog leucocyte antigen class II diversity and relationships among indigenous dogs of the island nations of Indonesia (Bali), Australia and New Guinea. Tissue Antigens 68, 418-426.

Sacks, B. N., Brown, S. K., Stephens, D., Pedersen, N. C., Wu, J-T., 6 and Berry, O. (2013). Y chromosome analysis of dingoes and Southeast Asian village dogs suggests a Neolithic continental expansion from Southeast Asia followed by multiple Austronesian dispersals. Molecular Biology and Evolution, 30, 1103-1118.

Savolainen, P., Zhang, Y., Luo, J, Lundeberg, J., and Leitner, T. (2002). Genetic evidence for an East Asian origin of domestic dogs. Science 298, 1610-1613.

Schiefenhövel, W. (2014). Human ethological perspectives on prehistoric adaptation and dispersal in the Central Highlands of New Guinea. In N. Sanz (Ed.) Human Origin Sites and the World Heritage Convention in Asia . pp. 235-254 (United Nations Educational, Scientific and Cultural Organization, Paris.)

Schultze-Westrum, T. (2010a). 'Papuan Dogs - the first companions of man.' Available at http://www.eco-communications.net/2010/11/11/papuan-dogs-the-first-companionsof-man-2 [accessed 10 April 2015].

Schultze-Westrum, T. (2010b). 'Papuan dogs - footnotes and research papers.' Available at http://www.eco-communications.net/2010/11/22/papuan-dogs-footnotes-andresearch-papers [accessed 10 April 2015].

Schultze-Westrum, T. (2010c). 'Papuan dogs - pictures.' Available at http://www.ecocommunications.net/2010/11/06/papuan-dogs-pictures-only [accessed 13 April 2015]. 
Shannon, L. M., Boyko, R. H., Castelhano, M., Corey, E., Hayward, J. J., McLean, C., White, M. E., Said, M. A., Anita, B. A., Bondjengo, N. I., Calero, J., Galov, A., Hedimbi, M., Imam, B., Khalap, R., Lally, D., Masta, A., Oliveira, K. C., Pérez, L., Randall, J., Tam, N. M., Trujillo-Cornejo, F. J., Valeriano, C., Sutter, N. B., Todhunter, R. J., Bustamante, C. D. and Boyko, A. R. (2015) Genetic structure in village dogs reveals a Central Asian domestication origin. Proceedings of the National Academy of Sciences, Early Edition, Available at www.pnas.org/cgi/doi/10.1073/pnas.1516215112 [accessed 21 October 2015]

Simpson, C. (1954). Shangri-La lies in times hands. The Argus 23 October 1954: 3.

Sinclair, J. P. (1955) Patrol Report Tari No. 7 - 1954/55. Report of a Patrol from Tari Station to the north-west, between Tari and the Strickland-Kagaip Rivers. [Copy held by authors.]

Speer, A. (1955) Patrol Report 7 - 1954/55. [Copy held by authors.]

Speer, A. (1956a) Letter to Sir Edward Hallstrom dated 31st May 1956. [Copy held by authors.]

Speer, A. (1956b) Letter to Sir Edward Hallstrom dated 5 August 1956. [Copy held by authors.]

Sutton, A., Mountain, M-J., Aplin, K., Bulmer, S., and Denham, T. (2009). Archaeozoological records for the highlands of New Guinea: a review of current evidence. Australian Archaeology 69, 41-58.

Tate, G. H. H. (1944). 'A List of the Mammals of the Japanese war area. Part 1 New Guinea and Eastward.’ (The American Museum of Natural History: New York.)

Tate, G. H. H. (1952). Results of the Archbold expeditions. No. 66. Mammals of Cape York Peninsula with notes on the occurrence of rainforest in Queensland. Bulletin of the American Museum of Natural History 98, 563-616.

Troughton, E. (1957). A new native dog from the Papuan Highlands. Proceedings of the Royal Zoological Society New South Wales 1955-1956, 93-94.

Troughton, E. (1971). The early history and relationships of the New Guinea Highland dog (Canis hallstromi). Proceedings of the Linnaean Society of New South Wales 96, 93-98.

Waddell, E, (1972). 'The Mound Builders: Agricultural Practices, Environment, and Society in the Central Highlands of New Guinea.' (University of Washington Press: Seattle.)

Wardlow, H. (2004). Anger, economy, and female agency: problematizing 'prostitution' and 'sex work' among the Huli of Papua New Guinea. Signs 29, 1017-1040.

Whitehead, H. (2000) 'Food Rules: Hunting, Sharing and Tabooing Game in Papua New Guinea.' (University of Michigan Press: Ann Arbor.)

Williams, F. E. (1924). 'The Natives of the Purari Delta.' (Government Printer: Port Moresby.)

Wobber, V., Hare, B., Koler-Matznick, J., Wrangham, R., and Tomasello, M. (2009). Breed differences in domestic dogs' (Canis familiaris) comprehension of human communicative signals. Interaction Studies, 10, 206-224. 
Wood-Jones, F. (1929). The cranial characters of the Papuan dog. Journal of Mammalogy 10, 329-333. 


\section{University Library}

\section{- M M I E R R V A gateway to Melbourne's research publications}

Minerva Access is the Institutional Repository of The University of Melbourne

Author/s:

Dwyer, PD;Minnegal, M

Title:

Wild dogs and village dogs in New Guinea: were they different?

Date:

2016-01-01

Citation:

Dwyer, P. D. \& Minnegal, M. (2016). Wild dogs and village dogs in New Guinea: were they different?. Australian Mammalogy, 38 (1), pp.1-11. https://doi.org/10.1071/AM15011.

Persistent Link:

http://hdl.handle.net/11343/59567 